\title{
Cytosolic Phospholipase A2 Beta
}

National Cancer Institute

\section{Source}

National Cancer Institute. Cytosolic Phospholipase A2 Beta. NCI Thesaurus. Code C38592.

Cytosolic phospholipase A2 beta (781 aa, $\sim 88 \mathrm{kDa}$ ) is encoded by the human PLA2G4B gene. This protein plays a role in glycerophospholipid metabolism. 